\title{
Merchant Account Books, Credit Sales, and Financial Development
}

\author{
Jeremy T. Schwartz ${ }^{1}$, David T. Flynn ${ }^{2} \&$ Gökhan Karahan ${ }^{3}$ \\ ${ }^{1}$ Youngstown State University, USA \\ ${ }^{2}$ University of North Dakota, USA \\ ${ }^{3}$ University of Alaska Anchorage, USA \\ Correspondence: Jeremy T. Schwartz, Youngstown State University, USA
}

Received: May 15, 2018

Accepted: June 14, 2018

Online Published: June 25, 2018

doi:10.5430/afr.v7n3p154

URL: https://doi.org/10.5430/afr.v7n3p154

\begin{abstract}
Credit in colonial New England, including the credit practices used by merchants, invites study beyond that in the existing literature which largely limits investigation to an individual merchant. Textual analysis of 56 merchant account books from Connecticut and Massachusetts across a breadth of the eighteenth century and conversion to Lawful Money allows a common quantification of the financial extent of merchant transactions throughout the century. Through some descriptive statistics and non-parametric tests, we find that use of book credit is ubiquitous and in amounts that imply that merchants were de facto financial intermediaries essential for the development of the economy.
\end{abstract}

Keywords: Colonial New England, financial development, credit sales

JEL Classifications: E44, E50, F36, F54, N91

\section{Introduction}

This study explores the different types of arrangements American colonists employed to coordinate economic activity and maintain an accurate system of accounting for transactions. Physical money was in short supply, perhaps arising from a Crown desire to control colonial activity. Nevertheless, American colonists traded with one another, extended credit to one another, and charged interest (in the form of higher prices) to those lacking current consideration for a purchase. We analyze 56 historical merchant account books in the New England colonies of Massachusetts and Connecticut to identify whether similar practices emerge within the region perhaps due to shared values, or, alternatively, whether dissimilar practices result based on differences in size, location, and merchant type.

Baxter (2004) explores the nature of money in the colonies and recognizes colonial ingenuity in recording events through merchant account books. The myriad methods of repayment imply that merchants and customers engaged in extensive and involved relationships. In fact, merchants could use account book credit for trade or for satisfying another obligation on another merchant's books. Given the well-known problem of paucity of coinage in the colonies, it appears that merchant account book credit serves ubiquitously as a substitute currency. Furthermore, Bridenbaugh $(1990,154)$ asserts, "From an economic point of view the use of credit was indispensable because of the shortage of circulating medium and it undeniably encouraged productive activity." Hawtrey (1950) makes similar comments in the context of what he terms the pure credit economy. These observations suggest that credit is efficient. Personal credit, these one-to-one loan extensions, was the best financing system available.

While the use of cash as a means of payment for goods and services has come to be viewed as superior to other methods, merchant account books show that credit facilitated a significant number of transactions despite the presence of early paper money issues. Merchants filled the lending role of the financial intermediaries the colonies lacked by issuing book credit in the form of account book entries. Indeed, the frequency and amount of book credit in the merchant's account book make them look more like dealers in finance, a definition used to describe a banker (see Hawtrey, 1950). Hollister and Schultz (2007) provide more recent support for the expanded role served by colonial merchants.

An important part of defining the actual repayment system in the colonies is matching the discussions from the larger literature regarding cash, barter or goods, and credit to the observed components. Our work here helps to assess the quality of the data contained in the account books, the literature on payments, and the actual form of the repayment system. The money supply at this time was not solely paper notes, so people accepted and used other items for 
payment and exchange as well. While colonists complained that an insufficient amount of media of exchange reduced the overall level of exchange in the economy, merchant account books provide evidence of the use of paper and other various items used to repay debts, as well as evidence about the actual sales. Using a larger sample drawn broadly from colonial merchants in Massachusetts and Connecticut, we contribute to the existing literature by providing more in-depth analysis about credit sales and repayment methods across merchant classes and over similar spans of time and region.

In the next section, we present a sampling of the relevant literature, followed by a discussion of business practices. Subsequently, we present entries in selected merchant account books themselves to give the reader a sense of their extensive intermediary role in terms of transaction volume. Finally, we harmonize the financial values across periods by standardizing amounts into Lawful Money to facilitate the comparison of the financial activities across the two colonies.

\section{Literature Review}

The colonial history literature provides detailed descriptions of economic life in the thirteen colonies. When the focus of research is the economic value of trade in the colonies, literature abounds. From an empirical standpoint, McCusker (1978), Jones (1980), McCusker and Menard (1985), Perkins (1988), and McCusker (1991) all contribute to our understanding of financial wealth and serve as benchmarks for our research in Colonial America during the seventeenth and eighteenth centuries.

When we narrow the focus to the extent and impact of merchant account book credit and its valuation in eighteenth century New England, significant studies include Martin (1939) and Baxter (1945). Martin (1939, 122) cites an extensive network of credit starting with English merchants shipping goods to the colonies. The generally accepted credit term is estimated at one year, consistent with the modern Accounts Receivable. The time limit required the receiving colonial merchant to move the goods quickly. One way to ensure this was through liberal use of credit. Martin $(1939,19)$ documents the dependence of Connecticut River valley merchants on credits from those in coastal cities, who in turn relied on credits from Boston and London.

Both Martin (1939) and Baxter (1945) use a limited sample of merchant account books as part of their investigations. Martin (1939) uses records of the prominent Dwight merchant family from Hartford in her study, while Baxter (1945) provides an intensive examination of the business records of the Hancock family from Boston. Baxter $(1945,46)$ further illustrates the dependence of the merchant Thomas Hancock on the credit, and good will, of suppliers in England.

The extensive literature is narrowed somewhat when the discussion centers on the ubiquity of credit. According to Bridenbaugh (1990, 153-154), "it is evident that very little cash changed hands in his [craftsman] shop. Money, particularly small change, was always scarce, ..." and "Credit rather than cash was the rule everywhere." Baxter $(1945,14)$ again illustrates Thomas Hancock's use of credit, “... although he valued what he bought and sold in terms of money, [he] seems to have handled money itself remarkably seldom."

The prevalence of credit as a means of facilitating transactions adds a new variable inviting attention since the variety of repayment options complicates matters for the colonial monetary literature. As Baxter (1945) notes, the ability to practice primitive bookkeeping allowed merchants to bypass the difficulties, primarily the double coincidence of wants, associated with contemporaneous barter exchanges. Baxter $(1945,20)$ coined the term "bookkeeping barter" (Note 1) to describe the use of goods for repayment of a sale originally recorded on credit. Both goods and cash appear in the account books, but usually in the fashion described by Baxter $(1945,21)$ : “...the accounts over and over again tell of the creditor's weary efforts to get his dues by accepting a tardy and halting series of odds and ends."

A consistent theme across the literature centers on the specification of media of exchange. Significant problems arise due to a lack of data on possibly significant elements such as specie amounts and commodity notes. Smith (1985, 538) excludes merchant book credit from his analysis and fails to appreciate the trading of credits between merchant accounts books, something that adds to the importance of including book credit in the analysis. Flynn (2005) provides evidence that such book credit often lasted beyond one year, implying that the credit itself functioned as a medium of exchange. More recently, Grubbs (2008) extensively studied the forms of money in the colonial US in the eighteenth century. Given that acceptable money was in short supply, and, thus, credit was of utmost importance in terms of being able to conduct vital economic transactions, our study shows how the different forms of credit contributed to economic and financial development of a significant subset (56 account books) of New England 
economy by presenting a far more comprehensive analysis than existing literature (generally one or two account books).

\section{Business Practices}

Most colonial New England merchants did not exclusively work as merchants since they also tended to their fields and livestock. Thus, the number of transactions per day was quite small. Merchants also acted in place of financial intermediaries that were non-existent in colonial New England. Merchants and customers used various forms of payment and repayment for the exchange of goods. To accurately assess credit practices, we must look at them in context. One source of great importance in this respect is the Journal of Madam Knight.

The journal is a record of the events witnessed by Sarah Knight on a trip from Brockton, Massachusetts to New Haven, Connecticut in the early eighteenth century. Knight $(1972,23)$ provides a candid account of merchant-customer exchanges:

Now, when the buyer comes to ask for a commodity, sometimes before the merchant answers that he has it, he sais, is Your pay redy? Perhaps the Chap reply's Yes: what do You pay in? say's the merchant. The buyer having answered, then the price is set.

"Redy" (sic) pay is current payment, rather than the use of credit. The price is then set based upon the payment offered. Before setting the price, the parties discussed two factors: the timing and type of payment. The merchant asks whether he is to receive payment immediately and receiving an answer inquires as to the type of payment. A situation where pay is not "redy" (sic) is an extension of credit requiring repayment.

Merchants accepted repayments in many forms, broadly classified as: Cash, Notes, Bond, Goods, Labor, and Reckoning. Repayment in goods after the fact recognizes the extension of credit rather than a simultaneous barter transaction. Customers and merchants can avoid the associated problems of barter when the merchant chooses to accept other methods of payment, including this delayed form.

Returning to Madam Knight $(1972,24)$, one can see the various methods of payment, both current and credit, available to customers.

Pay is Grain, Pork, Beef, \&tc. at the prices sett by the General Court that Year; mony is pieces of Eight, Ryalls, or Boston or Bay shillings (as they call them) or Gopd hard money, ats sometimes silver coin is termed by them; also Wampom viz Indian beads $w$ serves for change. Pay as mony is provisions, as afores one Third cheaper then as the Assembly of Gene Court sets it; and Trust as they and the merch agree for time.

"Pay" is also called "country pay" in other sources and is like the goods category mentioned earlier. Weiss (1970) speculates that the distinction between "pay" and "pay as mony" (sic) arose when the prices set by the General Court were not in line with market prices, but they both clearly involve the merchant accepting goods as payment. Knight's "mony" (sic) category is limited to minted coins, foreign and domestic, and Indian beads. "Pay as mony" (sic) are the same products from the earlier category though in this circumstance they are discounted by one third, though there is no reason to believe the one-third discount was an actual rule; the discount is indicative of merchants' recognition that market prices and government-set prices may diverge. The last method of payment listed is trust, essentially credit. Merchant and customer agree on a length of time waited for payment. The parties likely negotiate the method of repayment as well, though this is not necessarily the case.

Madam Knight (1972, 22-23) reports that merchants did exercise discretion when encountering customers who are indebted to them, relaying the following example that focuses on a country buyer and the merchant:

They [country fellows] Generally stand after they come in a great while speechless, and sometimes don't say a word till they are askt what they want, which I Impute to the Awe they stand in of the merchants, who they are constantly almost Indebted too; and must take what they bring without Liberty to choose for themselves; but they serve them was well, making the merchants stay long enough for their pay.

The implication that merchants choose what a customer can buy is striking. One way to interpret the activities described in this passage is as a form of rationing employed by the merchant. Only certain goods are allowed for those who are currently in debt to the merchant or are likely to require time for repayment. 
The above passages from Madam Knight provide insights into the way prices were set and that payments were complex undertakings with various instruments acceptable for satisfying account balances. Her tales reinforce the view presented in Baxter (1945) and developed here: Customers and merchants made use of more than just minted coins and paper notes in daily exchange. The mixed methods of payments bring up a further use for credit, that of making change. With insufficient supplies of money store credit may have been the most acceptable form of change available. With the formal definitions and general business practices in place, we next delineate how merchants recorded these exchanges.

\section{Account Books}

Merchant account books (Note 2) in this study are a mix of urban and rural accounts recording activity that occurred primarily within Massachusetts and Connecticut during the eighteenth century, though some books list transactions occurring near the border between colonies. People from other colonies enter the account books when merchants traded overseas. These merchants both sent and received shipments, always reducing amounts into local (their home colony) $£$. While cash may not have been prominent in the economy, the colonists recognized the efficiency of converting goods sales into currency units. The merchant then recorded the amount of the purchase or payment assessed in colony-specific $£$. Each colony had its own version of $£$ that fluctuated against sterling. The colonies were monetized in the sense that each used its own standard of value. Massachusetts, as the largest and most developed economy, set the pace for the rest of the region in terms of exchange in New England.

Merchant account books primarily record exchanges where the merchant does not receive full contemporaneous consideration and the customer promises to pay the merchant in the future. In some cases, the account books do record contemporaneous cash and barter sales, although these are usually believed to be unrecorded transactions since the customer had fully satisfied the obligation to the merchant.

Generally, the account books provide dates for transactions as well as a listing of what took place. The listing can be very specific, listing quantity of goods and per unit prices as well as the method of repayment, or it can be vague, simply saying "credit" or nothing at all. Estimating the span of time covered by a book is difficult in some cases. Some books record accounts by date and others by individual; the latter case makes determination of an end date for an account book difficult, though assessing the dealings between merchant and buyer is easier. The fragile condition of the books also makes statistical analysis challenging, especially in the cases where large parts of the book are missing.

\section{Account Book Entries}

Most merchants treated the account books in a way like an Accounts Receivable subsidiary ledger with the accounts for each separate individual occupying space on two facing pages. Corresponding to modern convention, the merchant recorded debits for sales to customers to the account on the left page and credits for payments made by customers on the right. Most accounts had columns on the page for the date, a description of the exchange often including a per-unit price, and for the total amount. Account books usually identified the customer clearly, though some problems exist. The merchant recorded the individual customer's name directly above the accounts for the first sale, often on both the left and right leaves. Successive sales and payments were added below earlier listings until no further space was available. Further account activity forced the merchant to total the debits and the credits and transfer the account to a new page in the same book or a different one. 


\begin{tabular}{|c|c|c|c|c|c|}
\hline & & Debit & & & Credit \\
\hline Date & Transaction & Pounds & Date & Transaction & Pounds \\
\hline $11 / 28 / 1749$ & $\begin{array}{c}\text { to } 12113 / 4 \text { of cheese } \\
@ 4 / 3\end{array}$ & 2.70 & & & \\
\hline $1 / 24 / 1750$ & to 311 of sugar @4/ & 0.60 & & & \\
\hline \multirow[t]{2}{*}{$2 / 10 / 1750$} & to 211 of ditto @5/ & 0.50 & & & \\
\hline & & & $7 / 18 / 1750$ & $\begin{array}{l}\text { by wiggs \& } \\
\text { shaving }\end{array}$ & 29.00 \\
\hline $7 / 27 / 1750$ & $\begin{array}{l}\text { to Earthen ware dld } \\
\text { Mr. Blair p yr order }\end{array}$ & 25.20 & & & \\
\hline $8 / 23 / 1751$ & $\begin{array}{c}\text { to Earthen ware to } \mathrm{Mr} \text {. } \\
\text { Blair }\end{array}$ & 3.38 & & & \\
\hline $12 / 16 / 1752$ & to ditto for ditto & 0.15 & & & \\
\hline $10 / 7 / 1756$ & $\begin{array}{l}\text { to Earthen Ware of } \\
\text { Jno. Harris for blair }\end{array}$ & 2.15 & & & \\
\hline
\end{tabular}

Figure 1. Account of Samuel Swan, customer, with Jonathan Parker, Merchant

Source: Parker, Jonathan. Account Book, 1747-1764. Mss: 605 1747-1817. Baker Library Historical Collections, Harvard Business School, Cambridge, Massachusetts, p. 12.

Figure 1 is a reproduction of the account between Samuel Swan, the customer and Jonathan Parker, a Massachusetts merchant. The table is fashioned to display the account much the same way it appeared in the original account book, with debits and credits recorded on two facing pages. Several individuals may be recorded on those two pages. The account book, methods, and practices of merchants will be discussed in more detail later. Swan made a purchase of cheese and two purchases of sugar on the dates shown in Figure 1. Each of these is interpreted as a separate loan, the total of all three being equal to £3.8. (Note 3) No payment was offered until five months after the third loan. Swan repaid his loans by "wiggs and shaving", suggesting something about Swan's profession, likely a wigmaker. The payment amount exceeded the total of the three loans, leaving Swan with a balance to draw down as he made further purchases, as recorded in Figure 1. It is important to note that these are nominal quantities as recorded by the merchant. Readers familiar with the colonial finance will know that the standard of value fluctuated throughout the eighteenth century. This issue will be addressed later in the section discussing the data sources.

The descriptions accompanying the sales and payments varied in the degree of detail, depending upon the merchant. Each transaction entry contains an explanation of each sale and payment. The sale on November 28, 1749 tells us the product, cheese, the amount, $123 / 4 \mathrm{lbs}$., and the price per pound, $4 \mathrm{~s} .3 \mathrm{~d}(4.25 \mathrm{~s}$.). Parker detailed the next two sale entries, for sugar, similarly. Parker received "wiggs and shaving" from Swan, though the accounts do not tell us the quantity. The remaining debits in Figure 1 are for sales of earthenware, but none consumed by Swan. These entries are an example of a triangular transfer of credit (see Baxter, 1945): Swan satisfied a debt owed Mr. Blair by ordering Parker to provide Blair with earthenware, using his surplus account with Parker to satisfy a debt elsewhere. When the activity involves a third-party, such as the debit entry dated 7/27/1750, the account names the third-party.

Occasionally merchants would perform a summation of the account. Called "reckoning"; it provides insight into more than just what the account book records. If the customer were another merchant, the reckoning would consider anything listed in the other's account book. Merchants made purchases from each other and used book credit just like their customers; there was no need for cash, goods, or other instruments to be used in exchange. After some period, the merchants totaled debits and credits to arrive at the net amount owed on the account. They would then compare the amounts each owed the other arriving at the net amount between them. At that time a payment could be offered to balance the account, or the merchants used the amount as a starting point and continued as before. 
Reckoning allowed merchants to focus their resources in other areas such as imports, investments, or capital expenditures and thus increased the productivity of business and the overall economy.

\section{Volume of Recorded Transactions}

The data are a sample of 56 separate account books from New England merchants, gathered from manuscript collections in Massachusetts and Connecticut historical societies. (Note 4) The data set is composed of 9,637 recorded sales with 4,299 recorded repayments for 13,936 total recorded observations.

\section{Recorded Sales}

We divide sales into categories consistent with the literature. There are two aspects considered to distinguish between types of sales: When was payment offered and what was offered as payment? Our research includes three categories for recording a sale: credit, cash, and barter. If no payment were offered at the time of sale, the merchant recorded the sale on credit. A current payment was either cash or barter, depending on what was offered in exchange. While cash is a broad category including government paper notes, personal paper notes and specie, barter transactions involve goods offered simultaneously as payment.

Table 1. Frequency of Recorded Sales by Category

\begin{tabular}{lcccc}
\hline & Total Recorded Sales & Credit & Cash & Barter \\
\hline Connecticut & $4108(100.0 \%)$ & $4051(98.6 \%)$ & $43(1.0 \%)$ & $14(0.3 \%)$ \\
Massachusetts & $5529(100.0 \%)$ & $5448(98.5 \%)$ & $57(1.0 \%)$ & $24(0.4 \%)$ \\
Total & $9637(100.0 \%)$ & $9499(98.6 \%)$ & $100(1.0 \%)$ & $38(0.4 \%)$ \\
\hline
\end{tabular}

Table 1 presents the number of recorded sales and relative frequencies from the account book data. Almost all these sales, $98.6 \%$ in Connecticut and $98.5 \%$ in Massachusetts, were on book credit. Payment at the time of purchase by cash and barter combine for less than $2 \%$ of recorded sales.

Cash and barter are spot transactions that do not result in any residual indebtedness; therefore, the merchant may not find it necessary to record them in the account book (Note 5). Cash and barter sales are likely underreported in the account books, but how severe is the bias? While the underrepresentation of such spot transactions in our data set precludes the ability to make definitive claims about the relative frequency of cash and barter use versus credit use in sales, Baxter (2004) cites one Connecticut merchant who estimates his split as $60 \%$ credit, $30 \%$ cash, and $10 \%$ barter. To put this in context, using our data, if account books report only one out of every hundred spot purchases, a significant bias, credit would still account for $40 \%$ of all purchases using the amount in Table 1. While it would not be the dominant form of payment in terms of frequency, credit would still be an important method of sale.

These findings are consistent with the works of Baxter (1945) and Bridenbaugh (1990) mentioned earlier. Moreover, the comprehensive nature of our study reveals that the two colonies were disparate in their relative financial development yet were so similar in their approach to facilitate commerce. Restricting specie failed to restrict market interactions.

\section{Recorded Repayments}

We have seven distinct repayment categories: Cash, Goods, Personal Notes, Third-party Notes, Reckoning, Labor, and Bond. Table 2 shows more clearly the use of several different items for exchange and repayment of credit. 
Table 2. Repayment Methods

\begin{tabular}{|c|c|c|c|c|c|c|c|}
\hline & \multirow{2}{*}{$\begin{array}{c}\text { Total } \\
\text { Repayments }\end{array}$} & \multicolumn{4}{|c|}{ Personal Third-party } & & \\
\hline & & Cash & Notes & Notes & Goods & Reckoning & gLabor Bond \\
\hline Connecticut & $\begin{array}{c}1779 \\
(100.0 \%)\end{array}$ & $\begin{array}{c}489 \\
(27.5 \%)\end{array}$ & $\begin{array}{c}59 \\
(3.3 \%)\end{array}$ & $122(6.9 \%)$ & $(45.9 \%)$ & $\begin{array}{c}134 \\
(7.5 \%)\end{array}$ & $\begin{array}{cc}159 & 0 \\
(8.9 \%) & (0.0 \%)\end{array}$ \\
\hline Massachusetts & $\begin{array}{c}2520 \\
(100.0 \%)\end{array}$ & $\begin{array}{c}621 \\
(24.6 \%)\end{array}$ & $\begin{array}{c}72 \\
(2.9 \%)\end{array}$ & $350(13.9 \%)$ & $\begin{array}{c}1219 \\
(48.4 \%)\end{array}$ & $\begin{array}{c}193 \\
(7.7 \%)\end{array}$ & $\begin{array}{cc}59 & 6 \\
(2.3 \%) & (0.2 \%)\end{array}$ \\
\hline Total & $\begin{array}{c}4299 \\
(100.0 \%)\end{array}$ & $\begin{array}{c}1110 \\
(25.8 \%)\end{array}$ & $\begin{array}{c}131 \\
(3.0 \%)\end{array}$ & $472(11.0 \%)$ & $\begin{array}{c}2035 \\
(47.3 \%)\end{array}$ & $\begin{array}{c}327 \\
(7.6 \%)\end{array}$ & $\begin{array}{cc}218 & 6 \\
(5.1 \%) & (0.1 \%)\end{array}$ \\
\hline
\end{tabular}

Goods play a significant role in the payments system. One of the more striking aspects of this table is the high number and frequency of repayment in Goods, almost twice the repayment in "Cash" and at least $45 \%$ of the repayments in both colonies.

Personal notes and third-party notes together appear as payment for book credit balances almost $14 \%$ in the two colonies combined. Third-party notes accounted for almost $14 \%$ of repayments in Massachusetts, as compared to less than $7 \%$ in Connecticut, and were much more widely used to satisfy debts than their first party counterparts (five times as often in Massachusetts and twice as often in Connecticut). It appears these notes circulated at least enough that people used another person's note rather than their own. According to Martin (1939, 157-158), merchants accepted the notes as a swap of one credit instrument for another because these notes could be used in other payments. The use of third-party notes in Table 2 was more than three times than of personal notes, strengthening this claim. While small compared to the use of goods for repayment, the result is important. The personal notes circulated, probably not as well as colony bills of credit, should nevertheless be added when addressing the issue of the amount of paper currency in circulation.

Labor was more prevalent in Connecticut, accounting for almost $9 \%$ of repayments, whereas it was only employed in a little more than $2 \%$ of repayments in Massachusetts. The larger Connecticut percentage is due mostly to larger rural representation in the Connecticut sample. In rural regions, it is more likely that the shopkeeper engages in other pursuits such as farming, increasing the options for payment (e.g., repaying your dry goods bill by plowing land). The presence of labor in the payment system is another example of a delayed barter arrangement.

It is noteworthy that the inclusion of personal and third-party notes as cash does not exceed goods as the most common form of repayment, lending support to Baxter's claim about merchants, that “....although he valued what he bought and sold in terms of money, [he] seems to have handled money itself remarkably seldom" (Baxter, 1945, 14). The fact that reckoning accounted for more than $7 \%$ of repayments in each colony provides further evidence.

Moreover, account evidence supports another of his claims, "the accounts over and over again tell of the creditor's weary efforts to get his dues by accepting a tardy and halting series of odds and ends" (Baxter, 1945, 21). These results present an additional problem: the lack of cash in repayments suggests limited circulation for both specie and notes, or they were too expensive relative to goods in payment. Our data seem to confirm the notion that creditors' receipt of "odds and ends" did not show a lack of cash use and barter, but rather they show a lack of cash and barter available at the time of sale. The bias against spot transactions may not be severe if customers and merchants substituted with credit and used cash and goods in the repayment of credit balances.

\section{Quantification of Transactions: Conversion to Lawful Money}

The account books supply more information about the relative importance of methods of sale and repayment than frequency of occurrence. While cash and barter transactions accounted for less than $2 \%$ of recorded sales, their importance may be understated if they were twice the value of credit sales.

\section{Nominal versus Real Amounts}

Comparisons of amounts across time are difficult to undertake, particularly for New England in this time. New England had two important standards for their currency, called old tenor and Lawful Money. (Note 6) A third standard, called middle tenor, also existed but merchants rarely used it in their accounts. The trouble arises from the fact that merchants kept accounts in pounds, but the silver value of the pounds changed over time. Old tenor 
values fluctuated over time while the Lawful Money standard, fixed the silver value of the colonial pound, resulting in an exchange rate of $£ 133.33$ Massachusetts to $£ 100.00$ sterling. Over the first half of the eighteenth century, the value of old tenor paper notes fell against the pound sterling. Massachusetts returned to the Lawful Money standard after March of 1750 and Connecticut returned after November of 1756 (McCusker, 1978, 135). Our data set includes some account books with values in old tenor and others with values in Lawful Money, requiring the adoption of a common standard for comparison sake, as well as further statistical work. Two reasons make Lawful Money the logical choice: first, many account books show merchants converting values from old tenor to Lawful Money; second, Lawful Money maintained a consistent value throughout the period.

While the choice of a base year is arbitrary, 1771 seemed reasonable since it is the approximate end date for the data. McCusker (1993, 323-325) again imparts assistance in Table A-2 from "How Much is that in Real Money?" providing price indices for all years covered in the data, allowing conversion to the base year.

Using a two-step process, we adjust the quantitative data obtained into Lawful Money with a standard year of 1771. Conversion between old tenor and Lawful Money is not a simple task. The first step is assessing which values need adjustment, a task made difficult by inconsistent merchant record keeping. The date of the sale or payment is a good indicator of whether the amount is old tenor or Lawful Money. Another indicator of the unit of account is whether the merchant performed an exchange calculation in the accounts. McCusker $(1978,135)$ eases the conversion process, where Table 3.1 in this book lists the monthly exchange rate between Massachusetts' old tenor and sterling, expressed as so many Massachusetts pounds per $£ 100$ sterling. One must divide the rates in the table by 133.33 to convert the old tenor-sterling exchange rates to old tenor-Lawful Money rates. The entries requiring conversion are mostly pre-1750 account entries, though some merchants continued old tenor use beyond that date. At this point it is possible to convert all values in Massachusetts into Lawful Money. The same table can be used for the Connecticut data except for the six years from March 1750 to November 1756, where new rates must be calculated due to the persistence of old tenor in Connecticut. McCusker (1978, Table 3.4) provides an approximation for the metallic rate of exchange for Connecticut from the years 1750 to 1760. Some comparisons may require conversion to a base year, mostly as a correction for inflation.

\begin{tabular}{|c|c|c|c|c|c|}
\hline $\begin{array}{c}\text { Sale } \\
\text { or } \\
\text { Repayment }\end{array}$ & Date & Transaction & $\begin{array}{l}\text { Total, } \\
\text { decimal. } £\end{array}$ & $\begin{array}{c}£ \text { Lawful } \\
\text { Money }\end{array}$ & $\begin{array}{c}£ \text { Lawful } \\
\text { Money } 1771\end{array}$ \\
\hline Sale & $8 / 18 / 1718$ & $\begin{array}{l}\text { to weaving } 25.75 \mathrm{yd} \\
\text { cotton and linen @10d }\end{array}$ & 1.07 & 0.714 & 0.811 \\
\hline Repayment & $8 / 19 / 1718$ & $\begin{array}{l}\text { by money rec'd by } \\
\text { hand of her sister } 4 / 4\end{array}$ & 0.22 & 0.144 & 0.164 \\
\hline Repayment & $1 / 21 / 1719$ & $\begin{array}{c}\text { by money rec'd by her } \\
\text { own hand } 15 /\end{array}$ & 0.75 & 0.471 & 0.512 \\
\hline Repayment & $8 / 20 / 1723$ & $\begin{array}{c}\text { Rec'd by Mr. } \\
\text { Edgecomb on account } \\
2 / 1\end{array}$ & 0.10 & 0.058 (Note 7) & 0.076 \\
\hline
\end{tabular}

Figure 2. Account of Catherine Coss, customer, with Isaac Huntington, Merchant of Connecticut

Sources: Huntington, Isaac. Account Book, 1717-1729. Manuscript Collections, Connecticut Historical Society, Hartford, Connecticut.

Exchange rates between old tenor and Lawful Money derived from McCusker, John J., Money and Exchange in Europe and America, 1600-1775: A Handbook, Chapel Hill: University of North Carolina Press, 1978, Tables 3.1 and 3.4.

Price index from Lawful Money (base 1771) from McCusker, John J. How Much Is That in Real Money? A Historical Price Index for Use as a Deflator of Money Values in the Economy of the United States. Proceedings of the American Antiquarian Society, Volume 101, Part 2. October 1991 
Figure 2 shows the process of these conversions and the adjustments they make to the account book values. The first column reports transaction type: Sale or Repayment. The next two columns provide the date and the account book description of the transactions. The fourth column presents the decimal pound amount of the original sale amount. The fifth and sixth columns convert the fourth column into Lawful Money and Lawful Money with a base year of 1771 .

Figure 2 displays the account between Catherine Coss, customer, and Isaac Huntington, a Connecticut merchant. Coss made one purchase from Huntington that required book credit. She made three payments on the account, the first being the next day after receiving the goods. The decimal pound column shows the nominal value of each entry. The conversion of the first entry into Lawful Money requires multiplying by 0.667, going from £1.07 to $£ 0.714$, introducing a slight error due to rounding. (Note 8) The first payment occurred the next day and, therefore, used the same exchange rate to Lawful Money. The second payment occurred the following year. An exchange rate of 0.628 between old tenor and Lawful Money adjusts the $£ 0.75$ to $£ 0.471$. The exchange rate for the final payment is 0.58 , reducing the payment of $£ 0.10$ old tenor to $£ 0.058$ Lawful Money. Adjusting the values to a base year of 1771 generates the numbers in the final column. The Lawful Money value for the sale increases from $£ 0.714$ to $£ 0.811$ when multiplied by a factor of 1.1358 from McCusker's table to convert it into base Year 1771 values. Figure 4 shows the payments adjusted likewise.

Conversions are a controversial topic. While some merchants made conversions from old tenor into Lawful Money, they did not explicitly consider price changes over time in their account books. Whether they did so implicitly is still an open question, but they do not tell us such in the account books. When the merchants mark an account as cleared or settled, should these conversions be used if they tell us something different? Moreover, many accounts span several years and sometimes decades, raising the issue of the time value of money. Despite these limitations, we believe that the ability to compare value directly through the conversion process overcomes all the issues introduced. Thus, all financial values in the following tables are reported in $£$ Lawful Money (1771).

\section{Individual Merchant Summaries}

Figures 3 and 4 present average entries (Note 9) for merchants in Connecticut and Massachusetts, respectively. Although we will discuss recorded sales and recorded repayments more fully below, we can recognize some similarities as well as some differences across these colonies. First, extension of credit is pervasive, with only one merchant failing to record a credit sale while contemporaneous cash and barter transactions occur on fewer merchant books. Recorded repayments appear most consistently as cash and goods, although other repayment types occur across the colonies. Looking more closely at recorded credit sales, Connecticut had two out of 25 merchants dealing in larger terms (greater than 5 pounds) while Massachusetts had eight out of 31 in this category; along the same lines, 21 out of 25 Connecticut merchants had average credit transactions between zero and one pounds, while only eight of the Massachusetts merchants fit into this classification. The general pattern is that the transactions in Massachusetts tended to be larger on average than those in Connecticut, yet the pattern of transactions were similar across colonies. (Note 10) 
Panel A: Recorded Sales

\begin{tabular}{|c|c|c|c|}
\hline \multirow[b]{2}{*}{ Merchant } & \multicolumn{3}{|c|}{$\underline{\text { Sales }}$} \\
\hline & Credit & Cash & Barter \\
\hline 1 & 16.072 & & 4.963 \\
\hline 2 & 0.081 & & \\
\hline 3 & 0.089 & & 0.000 \\
\hline 4 & 0.500 & & \\
\hline 5 & 0.574 & & \\
\hline 6 & 19.129 & 2.802 & \\
\hline 7 & 0.304 & & \\
\hline 8 & 0.276 & 0.176 & \\
\hline 9 & 0.368 & & \\
\hline 10 & 0.318 & 0.428 & 0.175 \\
\hline 11 & 0.401 & & \\
\hline 12 & 0.154 & & 0.088 \\
\hline 13 & 0.413 & 0.181 & 0.610 \\
\hline 14 & 0.557 & & \\
\hline 15 & 0.225 & & \\
\hline 16 & 0.184 & 0.026 & \\
\hline 17 & 0.123 & & \\
\hline 18 & 4.290 & 0.750 & \\
\hline 19 & 1.100 & 9.955 & \\
\hline 20 & 0.116 & & \\
\hline 21 & 0.196 & & \\
\hline 22 & 0.109 & & \\
\hline 39 & 0.465 & 0.748 & 0.067 \\
\hline 40 & 0.508 & 4.255 & \\
\hline 41 & 0.018 & & \\
\hline
\end{tabular}




\section{Panel B: Repayments}

\begin{tabular}{|c|c|c|c|c|c|c|c|}
\hline \multirow[b]{2}{*}{ Merchant } & \multicolumn{7}{|c|}{$\underline{\text { Repayments }}$} \\
\hline & Cash & Goods & Personal & Reckoning & Third-party & Bond & Labor \\
\hline 1 & 10.779 & 4.939 & & & & & \\
\hline 2 & 0.139 & 0.368 & & & & & \\
\hline 3 & 0.000 & 0.004 & 0.050 & 3.346 & 0.292 & & \\
\hline 4 & 0.518 & 0.936 & 18.588 & 9.808 & 2.307 & & 2.875 \\
\hline \multicolumn{8}{|l|}{5} \\
\hline 6 & 38.054 & 40.669 & 22.153 & 11.378 & 22.079 & & 1.108 \\
\hline 7 & & 0.200 & & 1.125 & & & 0.119 \\
\hline 8 & 1.004 & 6.824 & 4.322 & & & & \\
\hline 9 & 1.068 & 1.249 & & 5.697 & 0.970 & & 0.155 \\
\hline 10 & 0.571 & 0.423 & 1.485 & 1.645 & 1.191 & & 0.180 \\
\hline 11 & 3.100 & 1.567 & 4.312 & -0.040 & 9.940 & & 0.278 \\
\hline 12 & 0.250 & 1.009 & & 0.598 & & & 0.087 \\
\hline 13 & 1.008 & 0.736 & 3.332 & 2.270 & & & 2.592 \\
\hline 14 & & 0.151 & & & & & \\
\hline 15 & 0.477 & 0.449 & 0.702 & 0.067 & 1.685 & & 0.185 \\
\hline 16 & 0.178 & & & & & & \\
\hline 17 & 0.028 & 0.450 & 0.533 & 0.340 & 0.072 & & 0.324 \\
\hline \multicolumn{8}{|l|}{18} \\
\hline 19 & 2.466 & 0.643 & 7.798 & 2.599 & 1.590 & & 0.338 \\
\hline 20 & & 0.409 & & & & & 0.062 \\
\hline 21 & 0.202 & 1.348 & & & & & \\
\hline 22 & 0.202 & 0.370 & 0.605 & 0.295 & & & 0.387 \\
\hline 39 & 0.584 & 0.425 & & -0.142 & 0.376 & & 0.300 \\
\hline 40 & 0.920 & 0.766 & 1.430 & 1.871 & 1.162 & & 4.518 \\
\hline 41 & 0.000 & 0.030 & & 0.072 & & & 0.000 \\
\hline
\end{tabular}

Figure 3. Summary Activity by Connecticut Merchants, in $£$ Lawful Money (1771) 
Panel A: Recorded Sales

\begin{tabular}{|c|c|c|c|}
\hline \multirow[b]{2}{*}{ Merchant } & \multicolumn{3}{|c|}{$\underline{\text { Sales }}$} \\
\hline & Credit & Cash & Barter \\
\hline 23 & 14.713 & & \\
\hline 24 & 1.943 & & \\
\hline 25 & 13.314 & & \\
\hline 26 & 2.549 & & \\
\hline 27 & 4.493 & & \\
\hline 28 & 1.394 & & \\
\hline 29 & 40.547 & & \\
\hline 30 & & & \\
\hline 31 & 0.329 & & \\
\hline 32 & 14.464 & 6.362 & 16.957 \\
\hline 33 & 2.389 & & \\
\hline 34 & 117.695 & & \\
\hline 35 & 1.192 & & \\
\hline 36 & 3.482 & & 3.067 \\
\hline 37 & 0.270 & & \\
\hline 38 & 5.161 & 1.330 & 1.363 \\
\hline 42 & 0.342 & & \\
\hline 43 & 4.056 & 2.760 & 1.065 \\
\hline 44 & 6.792 & & \\
\hline 45 & 124.744 & 14.865 & 1.696 \\
\hline 46 & 4.137 & & \\
\hline 47 & 0.094 & & \\
\hline 48 & 1.982 & 1.389 & 0.442 \\
\hline 49 & 0.889 & & \\
\hline 50 & 1.476 & & 0.020 \\
\hline 51 & 0.040 & 0.000 & 0.000 \\
\hline 52 & 0.236 & & \\
\hline 53 & 0.149 & 0.000 & 0.000 \\
\hline 54 & 1.963 & & \\
\hline 55 & 1.865 & & \\
\hline 56 & 3.998 & & \\
\hline
\end{tabular}




\section{Panel B: Repayments}

\begin{tabular}{|c|c|c|c|c|c|c|c|}
\hline Merchant & Cash & Goods & Personal & Reckoning & Third-party & Bond & Labor \\
\hline 23 & 27.275 & 2.782 & 76.561 & 131.803 & 31.468 & -51.520 & \\
\hline 24 & 13.839 & -0.858 & & 78.306 & -4.094 & & 0.756 \\
\hline \multicolumn{8}{|l|}{25} \\
\hline 26 & 6.354 & 6.590 & & 2.104 & 11.140 & & 1.680 \\
\hline 27 & 9.019 & 12.703 & -1.000 & -1.222 & -0.832 & & 42.781 \\
\hline 28 & 0.447 & 0.328 & & 11.239 & & & \\
\hline 29 & & 46.291 & & & 97.132 & & \\
\hline 30 & 4.710 & 5.087 & 10.134 & 4.734 & & & \\
\hline 31 & 0.421 & 0.855 & & 1.319 & & & 0.158 \\
\hline 32 & 6.357 & 8.843 & 69.994 & 37.492 & 50.727 & 26.292 & 3.792 \\
\hline 33 & 3.714 & 2.646 & & 27.867 & & & 2.006 \\
\hline 34 & 318.708 & 81.418 & 48.221 & 490.986 & 68.760 & 149.813 & \\
\hline 35 & 1.519 & 35.443 & 0.236 & & & & \\
\hline 36 & 11.080 & 14.179 & & 36.864 & & & \\
\hline 37 & 0.734 & 1.167 & & & & & 0.055 \\
\hline 38 & 8.755 & 11.212 & 0.899 & 6.268 & & 25.403 & \\
\hline \multicolumn{8}{|l|}{42} \\
\hline 43 & 9.286 & 5.554 & 9.634 & 25.744 & 4.174 & 3.097 & 0.308 \\
\hline \multicolumn{8}{|l|}{44} \\
\hline 45 & 72.260 & 41.292 & 25.275 & 515.785 & 48.578 & & \\
\hline 46 & 8.108 & 22.685 & & 32.294 & 5.263 & & \\
\hline 47 & & & & 2.679 & & & \\
\hline 48 & 2.774 & 2.905 & 2.448 & 9.355 & 1.259 & & 2.942 \\
\hline 49 & 0.875 & 0.591 & 1.885 & 0.939 & 9.337 & & \\
\hline 50 & 2.473 & 1.351 & 0.000 & 2.297 & 1.343 & & 3.680 \\
\hline 51 & 0.037 & 0.701 & 0.000 & -1.955 & 0.187 & 0.000 & 0.000 \\
\hline 52 & & 0.000 & & & & & 0.000 \\
\hline 53 & 0.117 & 0.099 & 0.000 & 0.506 & 0.006 & 0.000 & 0.054 \\
\hline 54 & 1.582 & 1.609 & & -0.178 & 2.469 & & 1.227 \\
\hline 55 & & 15.773 & & 8.147 & & & 2.474 \\
\hline 56 & 3.503 & 5.814 & 7.217 & -0.996 & 2.134 & & 0.615 \\
\hline
\end{tabular}

Figure 4. Summary Activity by Massachusetts Merchants, in £ Lawful Money (1771) 


\section{Recorded Sales}

Table 3. Average Recorded Sale by Category, in £ Lawful Money (1771)

\begin{tabular}{lcccc}
\hline & Overall & Credit & Cash & Barter \\
\hline Connecticut & 1.123 & 1.097 & 3.252 & 1.960 \\
& & & & \\
Massachusetts & 13.733 & 13.896 & 4.638 & 5.920
\end{tabular}

Table 3 shows the large differences in the scale of business between the two colonies. Average credit in Massachusetts was usually more than ten times greater than that in Connecticut (£13.9 compared to £1.1). (Note 11) Recorded cash sales in Massachusetts are less than barter, $£ 4.64$ compared with $£ 5.92$, whereas in Connecticut cash sales exceed barter ( $£ 3.25$ v. £1.96).

To put these sales numbers in context, consider the financial estimates, in Lawful Money for 1771, that Jones (1980) and Perkins $(1988,218)$ provide for New Englanders: average physical wealth of $£ 124.95$, median wealth of $£ 57.35$, and mean income of $£ 8.4$. Simply put, the size of average transactions values in both colonies is impressive. The average Massachusetts credit sale of $£ 13.733$ Lawful Money exceeds the mean income estimate and is almost one-fourth of median wealth - for only an average credit transaction. Parts of the Massachusetts sample are clearly more developed and handling larger exchanges than rural Connecticut.

Table 4. Percentage of Total £ Lawful Money (1771) Recorded Sales, by Category

\begin{tabular}{llll}
\hline & Credit & Cash & Barter \\
\hline & & & \\
Connecticut & $96.4 \%$ & $3.0 \%$ & $0.6 \%$
\end{tabular}

Massachusetts $\quad 99.5 \% \quad 0.3 \% \quad 0.2 \%$

To further assess the frequency of each category, we calculate the share of the total amount (in $£$ ) of recorded sales and present them in Table 4. Credit was the major method used for purchasing goods in both colonies with well over $96 \%$ of the total value of sales in each, though it declines by around $2 \%$ for Connecticut. Recorded credit sales in Massachusetts were $99.5 \%$ of the total value of sales. Recorded cash sales in Connecticut were around $3 \%$ of value, about ten times the Massachusetts percentage. The barter percentage in Connecticut is three times the Massachusetts value. Owing to the small size of the recorded contemporaneous cash and barter sales, it remains an open question why merchants chose to record these contemporaneous cash and barter transactions. In any event, credit was a vital way to sell in both colonies, in amounts that make claims of credit's ubiquity valid.

\section{Recorded Repayments}

The same methodology applied to recorded sales can be applied to repayments. Table 5 presents the average repayment in £ Lawful Money (1771).

Table 5. Average Recorded Repayment by Category, in £ Lawful Money (1771)

Overall Cash Personal Notes Third-party Notes GoodsReckoningLabor Bond

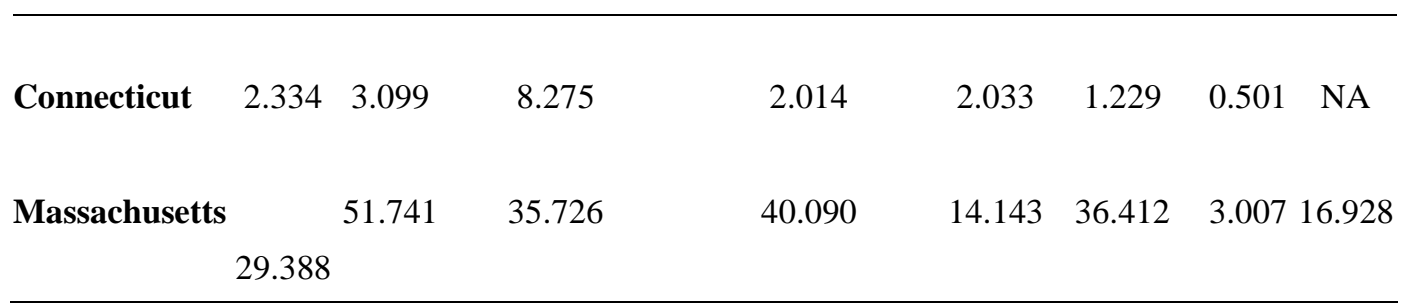

Average repayments in Massachusetts were far greater than those in Connecticut, confirming the differences in development. The average cash repayment in Massachusetts was seventeen times larger than in Connecticut, $£ 51$ 
compared to $£ 3$. The average cash transaction from the Massachusetts sample was almost as large as median New England wealth. While not as dramatic as the Massachusetts, the Connecticut numbers are large as well. It is not easy to imagine a payment being equal to one quarter of mean income.

Table 6. Percentage of Total $£$ Lawful Money (1771) Recorded Repayments, by Category

\begin{tabular}{lccccccc}
\hline & \multicolumn{7}{c}{ Personal Third-party } \\
& Cash & Notes & Notes & Goods ReckoningLabor Bond \\
\hline Connecticut & $36.5 \%$ & $11.8 \%$ & $5.9 \%$ & $39.9 \%$ & $4.0 \%$ & $1.9 \%$ & NA \\
& & & & & & & \\
Massachusetts & $43.9 \%$ & $3.5 \%$ & $19.1 \%$ & $23.6 \%$ & $9.6 \%$ & $0.2 \%$ & $0.1 \%$
\end{tabular}

Table 6 presents the percentage of total repayments that each category represented. Cash itself is the largest repayment category for Massachusetts at $44 \%$ while it is only $36.5 \%$ for Connecticut, ranking behind goods. Note that while Goods was the most prevalent repayment category in terms of frequency, its share of the total value of repayments in Connecticut was $39.9 \%$ but only $23.6 \%$ in Massachusetts. Reckonings take on an increased significance in Massachusetts (9.6\% of the total value) over Connecticut (4.0\%). Some of the more notable results include the differences between the two colonies in the use of notes. In Connecticut, the personal note accounts for $11.8 \%$ of all repayments and the third-party note only $5.9 \%$ whereas in Massachusetts the opposite occurs with personal notes equal to $3.5 \%$ and third-party notes equal to $19.22 \%$ of the total value of repayments. (Note 12)

\section{Conclusion}

This paper demonstrates credit ubiquity and describes the various repayment methods employed in colonial Massachusetts and Connecticut. Colonial merchants serve as financial intermediaries as lending practices evolved over the eighteenth century. As time passed merchants took on more intermediary functions. Customers were given acceptances to use in distant towns. Statements were sent to the merchant who paid the creditor to the customer. The merchant added corresponding amounts to the debt of the customer on his books.

Combined, these numbers illustrate some significant features of colonial economic life. Despite differences in scale of operations and repayment preferences, both colonies made extensive use of credit. The size of the sales and repayments are quite large, particularly for Massachusetts. When compared to Jones's estimates of wealth, our results take on an increased significance. Taken together, the size of the average credit transaction and the frequency of credit use demonstrate both credit's ubiquity and the importance of credit to the economy. The average repayment values show that goods and cash play important roles in the payment system. Even considering a systematic understatement of recorded cash sales, credit played critical role in the economy.

\section{Primary Sources}

Allin, Alexander. Account Book. Connecticut Historical Society, Hartford.

Amory, Thomas. Account Book. Massachusetts Historical Society, Boston.

Anonymous Blacksmith. Account Book. Connecticut Historical Society, Hartford.

Anonymous Doctor. Account Book. Connecticut Historical Society, Hartford.

Anonymous New Hampshire Merchant. Account Book. Massachusetts Historical Society, Boston.

Bancroft, Benjamin. Account Book. Connecticut Historical Society, Hartford.

Barker, Joshua. Account Book. Connecticut Historical Society, Hartford.

Belcher, William. Account Book. Connecticut Historical Society, Hartford.

Bevans, John. Account Book. Massachusetts Historical Society, Boston.

Boston Merchants. Account Book. Massachusetts Historical Society, Boston.

Bromfield, Henry. Cashbook. Harvard Business School, Baker Library.

Caldwell, Charles. Account Book. Connecticut Historical Society, Hartford.

Catlin, Ebenezer. Account Book. Connecticut Historical Society, Hartford. 
Chandler, William. Account Book. Massachusetts Historical Society, Boston.

Clark, John. Account Book. Massachusetts Historical Society, Boston.

Cobb, Joseph. Account Book. Harvard Business School, Baker Library.

Cushing, Pyam. Account Book. Harvard Business School, Baker Library.

Dean, John. Account Book. Connecticut Historical Society, Hartford.

Dean, Nathaniel. Account Book. Connecticut Historical Society, Hartford.

Dorr, Ebenezer. Account Book. Massachusetts Historical Society, Boston.

Dyer, Thomas. Account Book. Connecticut Historical Society, Hartford.

Eustis, Benjamin. Account Book. Massachusetts Historical Society, Boston.

Foster, Hopestill. Account Book. Harvard Business School, Baker Library.

Freeman, Constant. Account Book. Massachusetts Historical Society, Boston.

Gay, Fisher. Account Book. Connecticut Historical Society, Hartford.

Grant, Samuel. Account Book. Massachusetts Historical Society, Boston.

Griffin, Eliphat. Account Book. Harvard Business School, Baker Library.

Hale, Richard. Account Book. Massachusetts Historical Society, Boston.

Hubbard, Robert. Account Book. Connecticut Historical Society, Hartford.

Hubbell, Nathan. Account Book. Connecticut Historical Society, Hartford.

Kinne, Moses. Account Book. Connecticut Historical Society, Hartford.

Knight, Sarah. The Journal of Madam Knight. Boston: David R. Godine, 1972.

Manchester, Bayes. Account Book. Harvard Business School, Baker Library.

Marrett, Edward. Account Book. Harvard Business School, Baker Library.

Midden, Joseph. Account Book. Massachusetts Historical Society, Boston.

Miscellaneous Shipping Firm. Account Book. Massachusetts Historical Society, Boston.

New Haven General Store. Account Book. Connecticut Historical Society, Hartford.

Parker, Jonathan. Account Book. Harvard Business School, Baker Library.

Plummer, Ebenezer. Account Book. Connecticut Historical Society, Hartford.

Rea, Daniel. Account Book. Harvard Business School, Baker Library.

Reeves, Cockerl. Account Book. Harvard Business School, Baker Library.

Root, Timothy. Account Book. Connecticut Historical Society., Hartford.

Shove, George. Account Book. Harvard Business School, Baker Library.

Smith, Reuben. Account Book. Connecticut Historical Society, Hartford.

Starr, Jehosaphat. Account Book. Connecticut Historical Society, Hartford.

Stockbridge, Benjamin. Account Book. Massachusetts Historical Society, Boston.

Stokes, Jonathan. Account Book. Connecticut Historical Society, Hartford.

Storer, Ebenezer. Account Book. Harvard Business School, Baker Library.

Trumbull, Jonathan. Account Book. Connecticut Historical Society, Hartford.

Wolcott, Alexander. Account Book. Connecticut Historical Society, Hartford.

Young, Isaac. Account Book. Connecticut Historical Society, Hartford. 


\section{Secondary Sources}

Bailyn, B. (1979). The New England Merchants in the Seventeenth-Century (Cambridge: Harvard University Press).

Baker Library Historical Collections, Harvard Business School. Cambridge, Massachusetts.

Baxter, W.T. (1945). The House of Hancock-Business in Boston, 1724-75 (Cambridge, Massachusetts: Harvard University Press).

Baxter, W. T. (2004), "Accounting in colonial America - observations on money, barter and bookkeeping," Accounting Historians Journal, 31(1), 129-140. https://doi.org/10.2308/0148-4184.31.1.129

Bridenbaugh, C. (1990). The Colonial Craftsman (New York: Dover Publications).

Connecticut Historical Society. Hartford, Connecticut.

Flynn, D.T. (2005). The Duration of Book Credit in Colonial New England. Historical Methods: A Journal of Quantitative and Interdisciplinary History, 38(4), 168-177. https://doi.org/10.3200/HMTS.38.4.168-177

Grubb, F. (2008). Money Supply in the American Colonies. In: Palgrave Macmillan (eds) The New Palgrave Dictionary of Economics. Palgrave Macmillan, London

Hawtrey, R.G. (1950). Currency and Credit (Aberdeen: The University Press).

Hollister, J. and S. M. Schultz. (2007). The Elting and Hasbrouck store accounts: a window into eighteenth century commerce. Accounting History, 12(4), 417-440. https://doi.org/10.1177/1032373207081600

Jones, A.H. (1980). Wealth of a Nation to Be: The American Colonies on the Eve of the Revolution (New York: Columbia University Press).

Martin, M. (1939). Merchants and Trade of the Connecticut River Valley, 1750-1820. Smith College Studies in History, 25, (Northampton, Massachusetts: Department of History, Smith College).

Massachusetts Historical Society. Boston, Massachusetts.

McCusker, J.J. (1978). Money and Exchange in Europe and America, 1600-1775: A Handbook (Chapel Hill: University of North Carolina Press).

McCusker, J.J. (1991). How Much Is That in Real Money? A Historical Price Index for Use as a Deflator of Money Values in the Economy of the United States. Proceedings of the American Antiquarian Society, Vol. 101, Part 2.

McCusker, J.J., \& Menard, R.R. (1985). The Economy of British America, 1607-1789. (Chapel Hill: University of North Carolina Press)

Perkins, E.J. (1988). The Economy of Colonial America (New York: Columbia University Press).

Smith, B.D. (1985). American Colonial Monetary Regimes: The Failure of the Quantity Theory and Some Evidence in Favor of an Alternate View. Canadian Journal of Economics, 18, 531-565.

Weiss, R. (1970). The Issue of Paper Money in the American Colonies, 1720-1774. Journal of Economic History, 30(4), 770-784. 


\section{Notes}

Note 1. Baxter $(1945,20)$ refers to such an exchange, a credit sale later repaid by goods, as "bookkeeping barter." Since some of our merchants recorded sales with simultaneous goods (barter), we make a distinction when a delayed good or service is used to repay a credit sale (Goods).

Note 2. While Bailyn (1979) focuses on the merchant elite, we include a broad spectrum of merchants. Similarly, while Martin $(1939,139)$ distinguishes between wholesale merchants and retail merchants, we do not make such a distinction since classifications of this sort did not prevent a merchant who generally sold wholesale from breaking up an entire shipload of goods for retail sale in smaller units.

Note 3. For statistical analysis, we report amounts in decimal pounds instead of the older method of pound, shilling, and pence "£, s. d."

Note 4. One account is listed as an Anonymous New Hampshire merchant. Since his account book is in the Massachusetts Historical Society manuscript collection, he is included in Massachusetts for this analysis.

Note 5. Martin $(1939,150)$ found similar results in her account book research: "The entries represent transactions with those customers who did not pay at once on purchasing goods for Dwight [Timothy Dwight, a Hartford merchant] either made no record of immediate cash purchases, or else there were almost no such transactions".

Note 6. Tenor refers to a value scheme for a note.

Note 7. Notice that the amounts in the Lawful Money column do not balance, slightly more than $£ 0.04$ remains, almost ten pence, though the original account entries did balance.

Note 8. The entry in McCusker (140, Table 1) is $£ 200$, divided by 133.33 is approximately 1.5 old tenor to 1 Lawful Money, or a multiple of .667.

Note 9. Note that some of the converted amounts appear as a zero, rounded to three decimal places. We include these numbers in Tables 3 and 4 to distinguish between a very small amount and an absence of the transaction type.

Note 10. Even though our descriptive analytics reveal that there is considerable difference between the states, we also have conducted a Mann-Whitney $U$ test to see if there is a statistically significant difference between Massachusetts and Connecticut in terms of the magnitude of credit sales. At any conventional significance level, this difference exists.

Note 11. Median sales and repayments provide substantially similar results. We have not presented them for parsimony.

Note 12. We compared our repayment estimates to those of Martin (1939) for a comparable region over the period of interest. Using Martin's definitions, the total value of repayments in our sample satisfied by "Money", consisting of Cash, Personal Notes, and Third-party Notes, is 54.2\% in Connecticut, close to her estimate of 59.1\%. Massachusetts's repayments are fully two-thirds made in "Money" using these categories, showing more money usage than Connecticut. 